\title{
DA LI JE HISTOLOŠKA GRAĐA ADENOKARCINOMA PLUĆA U DIJAGNOSTIČKIM I TERAPIJSKIM UZORCIMA IDENTIČNA?
}

\author{
Tegeltija Dragana, Lovrenski Aleksandra, Vasiljević Tijana, Vanesa Sekeruš, Maksimović \\ Siniša, Kuhajda Ivan, Bijelović Milorad, Ivanić Milena, Miroslav Ilić
}

\begin{abstract}
Apstrakt
Uvod: Adenokarcinom (ADC) pluća ima heterogenu histološku građu. Dijagnostički uzorak (DU) može da bude citološki ili histološki, najčešće se dobija bronhoskopijom. Kompletna hirurška resekcija tumora predstavlja jedan od oblika lečenja obolelih od ADC.

Materijal i metode:U istraživanje je bilo uključeno 143 bolesnika sa dijagnostikovanim i hirurški lečenim ADC pluća od 2010. do 2015. na Institutu za plućne bolesti Vojvodine. Analizirani podaci su preuzeti iz istorije bolesti. Svi uzorci su reklasifikovani na osnovu kriterijuma SZO iz 2015. DU i terapijski uzorak (TU) sa jednim histološkim aranžmanom smo smatrali homogenim (Ho), heterogeni (He) su bili uzorci sa dva ili višse aranžmana.

Rezultati:U istraživanje je bilo uključeno 84 muškaraca i 59 žena, 94 (66\%) pušača, prosečne starosti od 66 godina. DU su u 76\% slučajeva dobijeni bronhobiopsijom i najčešće su bili Ho (69\%). TU dobijeni nakon lobektomije su bili najzastupljeniji (80\%), najčešce He (75\%). Acinarni i solidni histološki tip je bio najzastupljeniji u obe grupe uzoraka.

Cilj rada je bio da se utvrdi da li je histološka građa adenokarcinoma pluća u dijagnostičkim $i$ terapijskim uzorcima identična.

Zaključak:Iako postoji statistički značajna razlika između histološke građe ADC u TU i DU $(p<0,001)$ acinarni tip je najzastupljeniji histološki tip $(p=0,65883)$ uz podudaranje histoloških tipova kod 106/143 (74\%) bolesnika.
\end{abstract}

Ključne reči:Adenokarcinom, bronhobiopsija, hirurška terapija, histološka građa.

\section{Uvod}

Adenokarcinom pluća (ADC) je maligni tumor epitelnog porekla sa glandularnom diferencijacijom, produkcijom mucina ili ekspresijom pneumocitnih imunohistohemijskih markera. Češće se dijagnostikuje kod muškaraca, pušača i u šestoj deceniji $(1,2,3,4,5)$.

Dijagnoza ADC pluća se postavlja u patohistološkom i/ili citološkom uzorku koji predstavlja dijagnostički uzorak (DU). Patohistološki uzorci mogu da se dobiju: bronhobiopsijom (BB), transbronhijalnom biopsijom (TBB), kateter biopsijom (KB), transkutanom biopsijom, otvorenom biopsijom ili hirurškom resekcijom pluća. Uzorci za citološku analizu mogu da budu: eksfolijativni (sputum i pleuralni izliv), abrazivni (bronhijalno četkanje, bronhijalno ispiranje i bronhijalna lavaža) i uzorci dobijeni aspiracijom tankom iglom (vođenom endobronhijalnim ultrazvukom, transezofagealni, perkutani ili transtorakalni vođeni kompjuterskom tomografijom) (6).

Morfološka građa ADC pluća je heterogena u više od $70 \%$ slučajeva $(7,8,9)$. Postoji više histoloških aranžmana (HA): lepidični (LP), acinarni (ACN), papilarni (PAP), solidni (SOL) i mikropapilarni (MPP). U hirurškim uzorcima se procenjuje svaki HA, evidentira svaki zastupljeniji u $\geq 5 \%$ ukupnog uzorka. Procentualno najzastupljeniji HA predstavlja histološki tip ADC. Prognoza bolesti zavisi od histološkog tipa. Bolesnici sa ADC $\mathrm{u}$ kome je procentualno najzastupljeniji LP tip imaju dobru prognozu; intermedijerno kliničko ponašanje se beleži bolesnika sa ACN i PAP tipom, a loša prognoza je onih sa SOL i MPP tipom $\operatorname{ADC}(10,11$, 12).

Terapija ADC pluća je rezultat multidisciplinarnog i personalizovanog pristupa bolesnicima. Kompletna hirurška resekcija tumora je metoda izbora za bolesnike u ranom i lokalno proširenom stadijumu bolesti kada hirurški uzorak predstavlja ujedno i terapijski uzorak $(\mathrm{TU})(6,10)$. 
Cilj rada je bio da se utvrdi da li postoji li razlika između histološke građe ADC pluća u DU i TU.

\section{Materijal i metode}

Istraživanje je bilo retrospektivnog karaktera, sprovedeno je u Službi za patološko-anatomsku i molekularnu dijagnostiku Instituta za plućne bolesti Vojvodine u Sremskoj Kamenici u periodu od 2010. do 215. U retrospektivno istraživanje su bili uključeni bolesnici: kod kojih je dobijen biopsijski i/ili citološki DU, sa R0 resekcijom tumora, koji preoperativno nisu primali hemio $\mathrm{i} / \mathrm{ili}$ radioterapiju, koji nisu imali ranije dijagnostikovan ADC pluća ili drugih organa.

U svim biopsijskim DU je određen broj biopsijskih fragmenata $\mathrm{i}$ broj histoloških rezova koji je određen i u TU. Svi uzorci su reklasifikovani na osnovu kriterijuma SZO, podeljeni na: LP, ACN, PAP, SOL i MPP tip. Na osnovu broja zastupljenih HA sve uzorke smo podelili u dve grupe. U homogenu (Ho) grupu su svrstani uzorci sa jednim HA, a u heterogenu (He) grupu uzorci sa dva i više HA. Reklasifikaciju su izvršila dva patologa nezavisno, konačni nalaz je bio rezultat koncenzusa. U slučaju neslaganja traženo je mišljenje trećeg patologa. Patološki stadijum bolesti je određen na sedme TNM kalsifikacije. Demografski podaci (dob i pol), pušačke navike, metoda uzorkovanja DU i tip hirurške intervencije su preuzeti iz Zdravstvenog informacionog sistema naše ustanove.

Dobijeni rezultati su prikazani tabelarno i grafički pomoću pomoću Microsoft Office Excel-a, programa za statistička i tabelarna izračunavanja.

\section{Rezultati}

Od 143 bolesnika uključena u istraživanje muškaraca je bilo 84 (59\%), žena 59 (41\%), prosečne starosti od 66 (ranga od 42 do 82) godina.
Nepušača je bilo najmanje, neznatno više kod žena (19\% vs 11\%) (Tabela 1).

Tabela 1. Distribucija bolesnika prema prosečnoj starosti i pušačkim navikama.

\begin{tabular}{|l|c|c|}
\hline & Muškarci n (\%) & Žene n (\%) \\
\hline Broj (\%) & $84(59)$ & $59(41)$ \\
\hline Prosečna starost (god.) & 65,4 & 60,2 \\
\hline Pušači & $54(64)$ & $40(68)$ \\
\hline Bivši pušači & $21(25)$ & $8(13)$ \\
\hline Nepušači & $9(11)$ & $11(19)$ \\
\hline
\end{tabular}

Najzastupljeniiji patohistološki i citološki DU su dobijeni BB (76\%) i CT vođenom transtorakalnom punkcijom tankom iglom (71\%). Raspon broja biopsijskih fragmenata je iznosio od 1 do 7, prosečno dva (Slika 1.). Širok raspon smo uočili i kod broja histoloških rezova DU (od 4 do 44, prosečno $16,30 \pm 6,63)$. TU su sečeni prosečno na $9,4 \pm 3,47$ histoloških rezova.

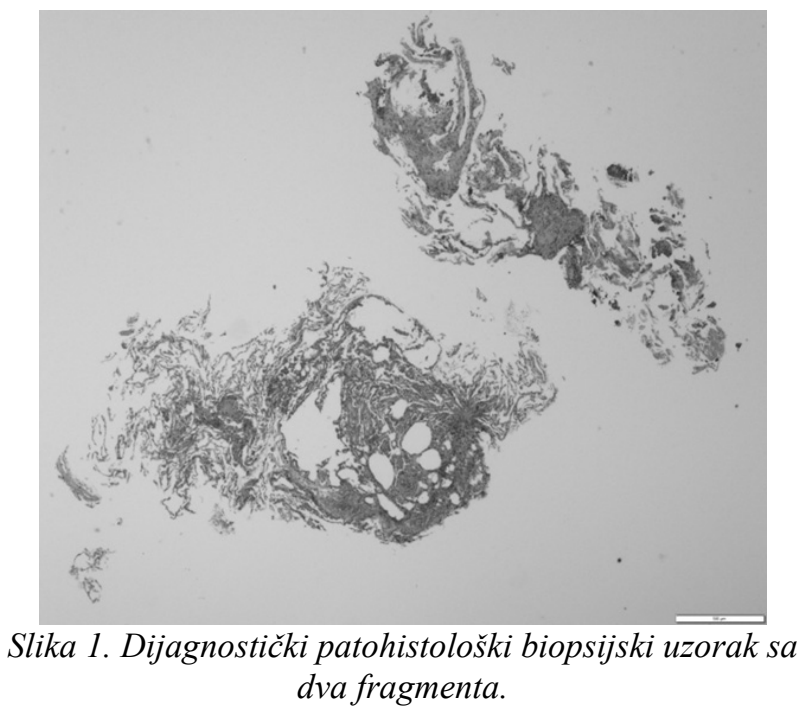

Ho grupa je bila zastupljeniji u odnosu na $\mathrm{He}$ grupu u DU (69\% vs 31\%) za razliku od TU gde je He grupa bila tri puta češća od Ho (Grafikon 1). 


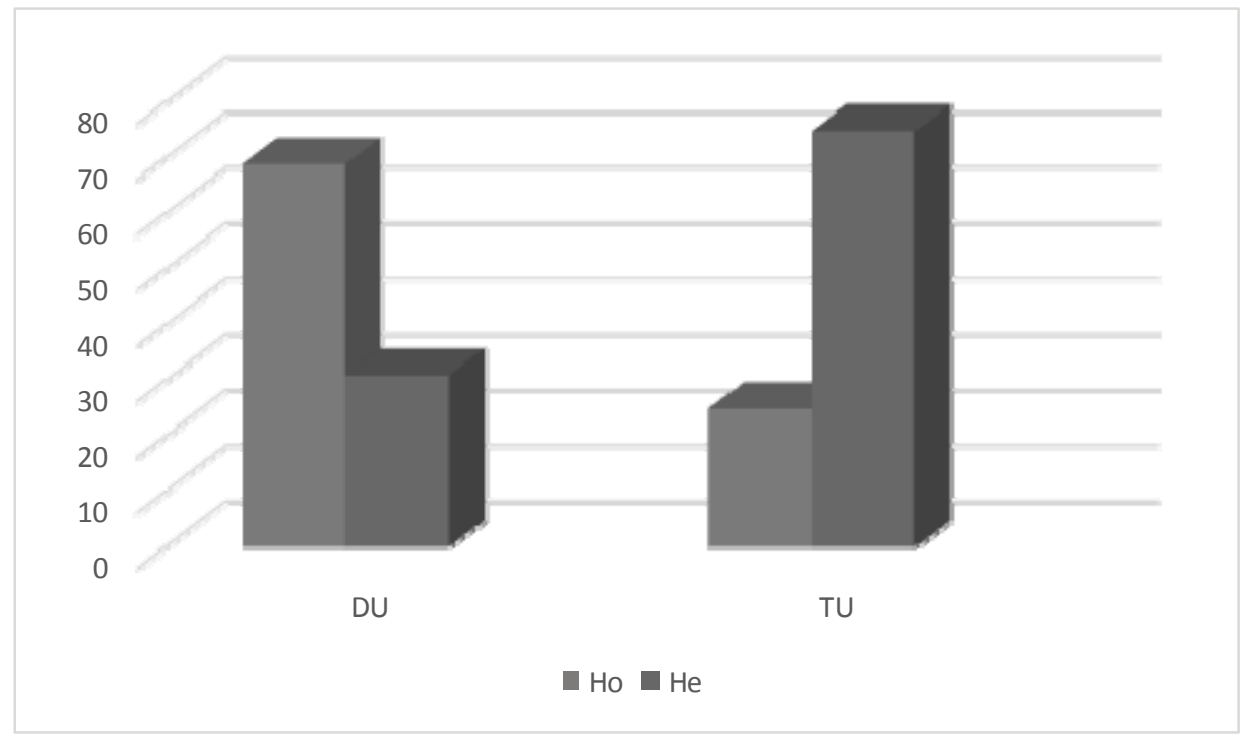

Grafikon 1. Zastupljenost homogene i heterogene grupe u dijagnostičkim i terapijskim uzorcima.

ACN i SOL histološki tip su bili najfrekventniji prisutno pet histoloških tipova HA koji su prikazani u DU (56\% i 35\%) i TU (50\% i 38\%). U TU je bilo grafički (Grafikon 2)

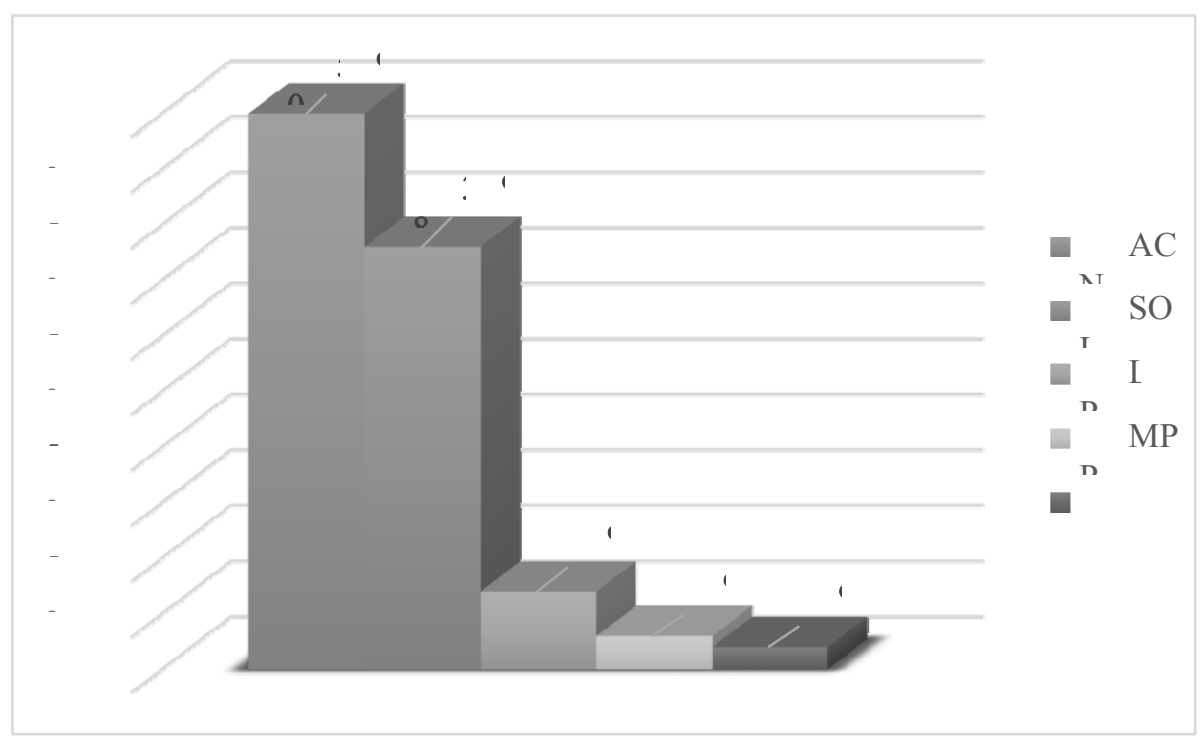

Grafikon 2. Distribucija histoloških tipova u terapijskim uzorcima.

Poklapanje HA između DU i TU je bilo predmet ovog istraživanja. Utvrđeno je da kod 106/143 (74\%) bolesnika postoji poklapanje HA između DU i TU (Tabela 2).

Tabela 2. Prikaz poklapanja HA između DU $i$ TU.

\begin{tabular}{|l|c|c|c|c|c|c|}
\hline \multirow{2}{*}{ TU } & \multicolumn{6}{|c|}{ DU } \\
\cline { 2 - 7 } & ACN & SOL & LP & PAP & MPP & Ukupno \\
\hline ACN & 58 & 9 & 1 & 3 & 1 & 72 \\
\hline SOL & 13 & 41 & 0 & 0 & 0 & 54 \\
\hline LP & 6 & 0 & 3 & 0 & 1 & 10 \\
\hline
\end{tabular}

\begin{tabular}{|l|c|c|c|c|c|c|}
\hline PAP & 1 & 0 & 0 & 2 & 0 & 3 \\
\hline MPP & 2 & 0 & 0 & 0 & 2 & 4 \\
\hline Ukupno & 80 & 50 & 4 & 5 & 4 & 143 \\
\hline
\end{tabular}

Kod $80 \%$ bolesnika je urađena lobektomija sa R0 resekcijom najčešće u IIB stadijumu bolesti $(75 / 143$; $52,5 \%$ ), najređe u Ia stadijumu bolesti sa procentualnim udelom od $9 \%$. 


\section{Diskusija}

ADC pluća je češći kod muškaraca, starijih i pušača. $(4,13,14,15,16,17,18)$. Taj stav su potvrdili i rezultati našeg istraživanja u kome je muškaraca bilo više (59\%), prosečna starost je iznosila 66 god. Najmanji broj bolesnika je bio u grupi nepušača, kod oba pola ( $11 \%$ muškaraca i 19\% žena).

Ključnu ulogu u dobijanju DU, određivanju endoskopske proširenosti bolesti, proceni operabilnosti tumora i dobijanju uzorka za molekularno testiranje ima bronoskopija, koja se u našoj ustanovi se sprovodi od 1960. $(5,19,20)$. Senzitivnost i specifičnost ove metode zavisi od endoskopskog nalaza i broja biopsijskih fragmenata. Preporuka je da se uzorkuje tri do pet fragmenata čija veličina zavisi od tehničkih performansi bronhoskopa i stručne osposobljenosti bronhologa (21). Količina tumora u DU je mala, zavisi od: histološkog tipa, endoskopskog nalaza i od tehnike uzorkovanja $(18,22)$. S obzirom na to da se biopsijski fragmenti nakon kalupljenja $\mathrm{u}$ parafin $\mathrm{u}$ sklopu standardne obrade seku na više histoloških rezova dolazi do ,potrošnje“ tumorskog tkiva. DU su kod velikog broja bolesnika jedini dostupan materijal za molekularno testiranje, stoga je potrošnju neophodno svesti na minimum. Broj biopsijskih fragmenata u publikovanim radovima je različit. Coghlin sa saradnicima je u analizi 100 endobronhijalnih biopsija evidentirao prosečno 3,3 biopsijskih fragmenta (od 1-6) (22). U studiji sa 2211 bolesnika (2009.-2011.) ADC je dijagnostikovan kod 108/452 bolesnika, sa prosečno četiri fragmenata (od 1-7), od kojih je 92,6\% uzoraka bilo sa tri do pet fragmenata (18). Mi smo u ovom istraživanju evidentirali prosečno 2 biopsijska fragmenta i prosečno $16,30 \pm 6,63$ (u rasponu od 4 do 44) histoloških rezova što je značajno manje u odnosu na rezultate ovih autora.

Lobektomija se primenjuju samostalno ili udružena sa hemioterapijom i/ili radioterapijom da bi se postigla poželjna R0 resekcija tumora. Preduslov za hirurški vid lečenja je resektabilnost tumora i dobro opšte stanje bolesnika. Kako je period bez recidiva bolesti i bolje preživljavanje najbolje kod bolesnika sa lobektomijom ova hirurška metoda je izvođena kod $80 \%$ bolesnika uključenih u naše istraživanje. Prema svetskim preporukama iz tumora se uzima po jedan uzorak po
$1 \mathrm{~cm}$ veličine tumora tako da se prikaže odnos tumora sa velikim krvnim sudovima i pleurom kao i svi resecirani limfni čvorovi. Rezultati našeg istraživanja su pokazali da postoji relativno slaba korelacija između broja isečaka iz tumora i veličine tumora $(\mathrm{r}=0,31)$. Raspon broja histoloških rezova iz TU u našem istraživanju je najpribližniji rezultatima Yoshizaw-e i Sun-a $(15,23)$. Uzimajući u obzir činjenicu da se patolozi uključeni u ovo istraživanje u svakodnevnom radu bave isključivo plućnom patologijom smatramo da su dobro trenirani $u$ proceni HA i invazije pleure i krvnih sudova. U našem istraživanju najviše bolesnika je bilo u IIB $(52,5 \%)$ stadijumu bolesti. Ovi rezultati su suprotni rezultatima drugih autora (24) što je najverovatnije posledica različitih inkluzionih kriterijuma između istraživanja.

Više od 70\% ADC pluća ima više od jednog HA $(23,25,26,27)$. Ovaj stav su potvrdili i rezultati našeg istraživanja. He tumori bili tri puta zastupljeniji od Ho u TU kao i da je ACN tip bio najfrekventniji u DU i TU. Ovi rezultati su saglasni sa rezultatima Solisa, ali sa značajno manjim procentualnim udelom ACN tipa.

\section{Zaključak}

1. Iako je heterogenost adenokarcinoma u terapijskim uzorcima veća u odnosu na heterogenost adenokarcinoma u dijagnostičkim uzorcima $(\mathrm{p}<0,001)$.

2. Acinarni histološki tip adenokarcinoma je najzastupljeniji histološki tip u dijagnostičkim i terapijskim uzorcima $(\mathrm{p}=0,65883)$.

3. Histološki tip adenokarcinoma u dijagnostičkim i terapijskim uzorcima je identičan kod 106/143 (74\%) bolesnika.

\section{Literatura:}

1. Adler I. Primary malignant growths of the lungs and bronchi. New York: Longmans, Green; 1912.

2. International Agency for Research on Cancer: GLOBOCAN 2012; Estimated cancer incidence, mortality and prevalence worldwide in 2012. International Agency for Research on Cancer, Lyon, France 2012. Available from: http://globocan.iarc.fr Accessed February 12, 2013.

3. Henley JS, Richards TB, Underwood MJ, Eheman CR, Plescia M, Timothy A, et al. Lung cancer 
incidence trends among men and women United States,2005-2009. MMWR.2014 Jan 10;63(1):1-5.

4. El-Basmy A. Profile of lung cancer in Kuwait. Asian Pac J Cancer Prev. 2013;14(10):6181-4.

5. Lewis DR, Chen HS Lewis DR, Chen HS, Feurer EJ. SEER Cancer statistics review, 1975-2008. Bethesda, MD National Cancer Institute; 2010. Available

from: http://seer.cancer.gov/csr/1975 2010/. Accessed October 20, 2013.

6. Hajmanoochehri F, Mohammadi N, Zohal MA, Sodagar A, Ebtehaj M. Epidemiological and clinicopathological characteristics of lung cancer in a teaching hospital in Iran. Asian Pac J Cancer Prev. 2014;15(6):2495-500.

7. Suda K, Sato K, Shimizu S, Tomizawa K, Takemoto $\mathrm{T}$, Iwasaki $\mathrm{T}$, et al. Prognostic implication of predominant histologic subtypes of lymph node metastases in surgically resected lung adenocarcinoma. BioMed Res Int. 2014;2014:64581 .

8. Russell PA, Barnett SA, Walkiewicz M, Wainer Z, Conron M, Wright GM, et al. Correlation of mutation status and survival with predominant histologic subtype according to the new IASLC/ATS/ERS lung adenocarcinoma classification in stage III (N2) patients. J Thorac Oncol. 2013 Apr;8(4):461-8.

9. Furukawa M, Toyooka S, Ichimura K, Yamamoto H, Soh J, Hashida S, et al. Genetic alterations in lung adenocarcinoma with a micropapillary component. Mol Clin Oncol. 2016;4(2):195-200.

10. Travis WD, Brambilla E, Noguchi M, Nicholson AG, Geisinger KR, Yatabe Y, et al. The new IASLC/ATS/ERS international multidisciplinary lung adenocarcinoma classification. J Thorac Oncol. 2011;6(2):244-85.

11. Prudence R, Zoe W, Gavin W, Marissa D, Matthew C, Richard W. Does lung adenocarcinoma subtype predict patient survival? A clinicopathologic study based on the new International Association for the Study of Lung Cancer/American Thoracic Society/European Respiratory Society international multidisciplinary lung adenocarcinoma classification. Thorac Oncol. 2011Sep;6(9):1496504.

12. Yoshizawa A, Motoi N, Riely G, Sima CS, Gerald WL, et al. Impact of proposed IASLC/ATS/ERS classification of lung adenocarcinoma: prognostic subgroups and implications for further revision of staging based on analysis of 514 stage I cases. Mod Pathol. 2011. May;24(5):653-64.
13. Jemal A, Siegel R, Xu J, Ward E. Cancer statistics, 2010. CA Cancer J Clin. 2010 Sep-Oct;60(5):277300.

14. Malvezzi M, Bertuccio P, Levi F, La Vecchia C, Negri E. European cancer mortality predictions for the year 2012. Ann Oncol. 2012;23(4):1044-52.

15. Yoshizawa A, Sumiyoshi S, Sonobe M, Kobayashi M, Fujimoto M, Kawakami F, et al. Validation of the IASLC/ATS/ERS lung adenocarcinoma classification for prognosis and association with EGFR and KRAS gene mutations: analysis of 440 Japanese patients. J Thorac Oncol. 2013 Jan;8(1):5261.

16. Stojšić J, Adzić T, Marić D, Subotić D, Milovanović I, Milenković B, et al. Histological types and age distribution of lung cancer operated patients over a 20-year period: a pathohistological based study. Srp Arh Celok Lek. 2011 Sep-Oct;139(9-10):619-24.

17. Paliogiannis P, Attene F, Cossu A, Defraia E, Porcu $\mathrm{G}$, Carta A, et al. Impact of tissue type and content of neoplastic cells of samples on the quality of epidermal growth factor receptor mutation analysis among patients with lung adenocarcinoma. Mol Med Rep. 2015 Jul;12(1):187-91.

18. Zhu P, Pan Q, Wang M. Efficacy of bronchoscopic biopsy for the detection of epidermal growth factor receptor mutations and anaplastic lymphoma kinase gene rearrangement in lung adenocarcinoma. Thorac Cancer. 2015 Nov;6(6):709-14.

19. Balaban G, Žikić T, Perin B, Čanak V, Kopitović I, Jovanović S. Operabilnost bolesnika sa centralnim karcinomom bronha i atelektazom. Pneumon. 1998;36(1-4):11-4.

20. Wang S, Yu B, Chiu Chin Ng, Mercorella B, Selinger CI, O'Toole SA, et al. The suitability of small biopsy and cytology specimens for EGFR and other mutation testing in non-small cell lung cancer. Trans Lung Cancer Res. 2015 April; 4(2):119-25.

21. Gellert AR, Rudd RM, Sinha G, Geddes DM. Fiberoptic bronchoscopy: effect of multiple bronchial biopsies on diagnostic yield in bronchial carcinoma. Thorax. 1982 Sep;37(9):684-7.

22. Coghlin CL, Smith LJ, Bakar S, Stewart KN, Devereux GS, Nicolson MC, et al. Quantitative analysis of tumor in bronchial biopsy specimens. J Thorac Oncol. 2010 Apr;5(4):448-52.

23. Sun Y, Yu X, Shi X, Hong W, Zhao J, Shi L. Correlation of survival and EGFR mutation with predominant histologic subtype according to the new lung adenocarcinoma classification in stage IB patients. World J Surg Oncol. 2014 May;12:148.

24. Liang Z, Zhang J, Zeng X, Gao J, Wu S, Liu T. Relationship between EGFR expression, copy 
number and mutation in lung adenocarcinomas. BMC Cancer. 2010 Jan;10(1):376.

25. Solis LM, Behrens C, Raso MG, Lin HY, Kadara H, Yuan $\mathrm{P}$, et al. Histologic patterns and molecular characteristics of lung adenocarcinoma associated with clinical outcome. Cancer. 2012 Nov;118(11):2889-99.
26. Stenhouse G, Fyfe N, King G, Chapman A, Kerr KM. Thyroid transcription factor 1 in pulmonary adenocarcinoma. J Clin Pathol. 2004 Apr;57(4):3837.

27. Furukawa M, Toyooka S, Ichimura K, Yamamoto H, Soh J, Hashida S, et al. Genetic alterations in lung adenocarcinoma with a micropapillary component. Mol Clin Oncol. 2016;4(2):195-200.

\section{Abstract}

Introduction: Lung adenocarcinoma (ADC) has heterogenous histological patterns. Diagnostic sample (DS) can be citologic or histologic and is most often acquired by bronchoscopy. Complete surgical tumor resection is one of the forms of treatment for patients with ADC.

Material and methods: Study included 143 patients with diagnosed and surgically treated LAC from 2010 to 2015 at Institute of Lung Diseases od Vojvodina. Analyzed data were obtained from medical history. All the samples were reclassified according to WHO from 2015 criteria. DS and therapeutical sample (TS) with one histological sample were considered as homogenous (Ho) and samples with two or more patterns were considered heterogenous (He).

Results: Study included 84 males and 59 females, 94 (66\%) smokers and average 66 years of age. DS were bronchoscopically aquired in $76 \%$ of the cases and were 69\% Ho. Lobectomy aquired TS were most frequent in our study and 75\% He. Acinar and solid pattern was most frequent in both sample groups.

The aim was to determine is histological pattern of lung adenocarcinoma identical in diagnostic and therapeutical samples.

Conclusion: Although there is statistically significant difference between ADC in TS and DS $(p<0,001)$, acinar histological pattern is the most frequent $(p=0,65883)$ and matching of histological patterns is achieved in 106/143 patients (74\%).

Key words: Adenocarcinoma, bronchial biopsy, surgical therapy, histologic pattern.

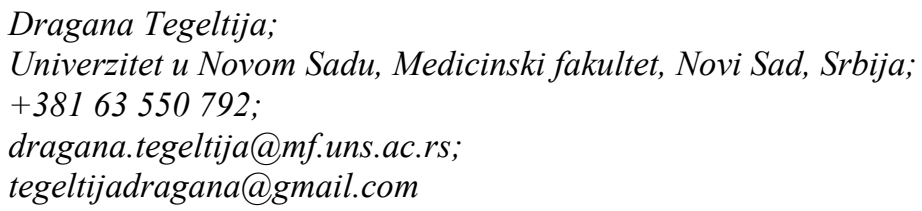

